\title{
Vokaalreëls by Dowes
}

\author{
Santie E Meyer \\ Department of Speech Pathology and Audiology \\ University of the Witwatersrand
}

\section{OPSOMMING}

Alhoewel die bepaling van reëlmatighede in spraakproduksie belangrik vir terapiebeplanning is, is dit nie altyd identifiseerbaar in die spraak van die dowe nie. Die doel van die studie was om te bepaal of die normaalhorende luisteraar in staat is om die dowe se spraakreëls te identifiseer. Sewe dowes met 'n kongenitale, sensoriesneurale gehoorverlies het ses toetsvokale in woorde vyf keer herhaal wat deur derdejaarstudente in Oudiologie in 'n geslote-keuseformaat beoordeel is. Twee luisteraars moes saamstem in 70\% van die beoordelings dat 'n spesifieke vokaal gehoor is. Uit die beoordelingsmatrikse blyk dit dat die luisteraars wel in staat was om konstanthede te identifiseer. Die interluisteraarkorrelasies wissel van $r=0.49$ tot 0.89 , wat impliseer dat die luisteraars nie altyd saamstem in hulle beoordelings van' $n$ spesifieke vokaal nie. Die bevinding het implikasies vir die oudioloog in terme van spraakevalusie.

\section{ABSTRACT}

Although the establishment of patterns in speech production is important for therapy planning they are not always identifyable in the speech of the deaf. In this study the object was to ascertain whether the normal hearing person was capable of identifying rules of speech. Seven deaf speakers with a congenital, sensori-neural hearing loss repeated six test words five times which were rated by third year Audiology students in a closed set format. Two listeners were required to agree in $70 \%$ of the cases that a specific vowel was heard. The rating matrixes showed that the listeners were able to identify consistencies. The interlistener correlations varied from $r=0.49$ to 0.98 , implying that the listeners did not always agree in their judgements regarding a specific vowel. In terms of speech evaluation the findings pose implications for the audiologist.

Ten spyte van uitgebreide navorsing en verbetering in die spraakopleidingstegnologie word die spraak van die dowe steeds gekenmerk deur swak verstaanbaarheid (Gold, 1980). Nogtans word spraakverbetering by dowe kinders aangemoedig en ook deur hul begeer om onafhanklike funksionering in die breë samelewing te vergemaklik (Ling, 1976; Manilal, 1992). Voortgesette pogings tot beter begrip van die spraakproduksie van die dowe en dus meer effektiewe spraakevaluasie en -terapie bly 'n navorsings-prioriteit.

Afgesien van die swak spraakverstaanbaarheid, word die dowe se spraakpogings ook deur 'n hoë mate van produksie-onstabiliteit of intrapersoonsvariasie in herhaling van dieselfde uitings, gekenmerk (Harris, Rubin, Spitz \& McGarr, 1985; Metz, Schiavetti, Sitler \& Samar, 1990; Osberger, 1987). Desnieteenstaande is daar aanduidings dat sprekers konstante verskille tussen sekere uitings aanbring (Monsen 1976). Hierdie konstante verskille kan as spraakpatrone of spraakreëls ${ }^{1}$ beskou

\footnotetext{
Spraakreëls is die produksiereëls waarvolgens spraakklanke op dieselfde, konstante wyse uitgespreek word en op 'n konstante wyse van ander spraakklanke verskil (verwerk uit Grunwell, 1982).
}

word.

Spraakreëls ontwikkel waarskynlik by die gehoorgestremde (daar word hier spesifiek na die persoon met'n binourale kongenitale ernstige tot totale sensoriesneurale gehoorverlies verwys) op dieselfde wyse as by die normaalhorende. Die omgewingsleidrade wat deur die gehoorgestremde gebruik word, sal waarskynlik van die normaalhorende verskil in die sin dat visuele en slegs gedeeltelike ouditiewe inligting (meestal lae frekwensieinligting) beskikbaar en dus benutbaar is (Boothroyd, 1978). Daar kan verder verwag word dat die gehoorgestremde se reseptiewe leidraadsisteem uitgebrei en gemodifiseer sal word soos in die geval van die normaalhorende kind, afhangende van die gehoorgestremde se omgewing en sy vermoë om spraak uit die omgewing, te gebruik (Fry, 1978). Hy ontwikkel dus 'n sisteem wat as konstanthede of reëlmatighede in sy spraak geïdentifiseer kan word, of te wel spraakreëls. Dit is egter' $n$ kontensieuse hipotese want daar is navorsers wat beweer dat daar nie sprake van 'n reëlgebaseerde sisteem in die dowe se spraak is nie as gevolg van die hoë mate van variasie in produksie (Harris et al., 1985). Hierteenoor beweer ander outoriteite dat daar nie bewys kan word dat die uitings op 'n lukraak wyse en dus sonder enige plan, geskied nie (Monsen, 1974; 
Monsen, 1976).

Die verskil in mening is nog nie besleg nie veral aangesien dit vir die spraakopleier ${ }^{2}$ so problematies is om hierdie spraakreëls te identifiseer. Die reëlmatighede in die produksie van die dowe se spraak is soms deur die normaalhorende luisteraar identifiseerbaar maar in vele gevalle nie. Selfs waar die dowe se spraakproduksie deur middel van die Internasionle Fonetiese Alfabet (IFA) getranskribeer word, is die gevaar dat die spreker se komplekse reëlsisteem vereenvoudig word deur die transkripsie (Parker \& Rose, 1990). Verder is die onakkurate segmente dikwels moeilik artikulatories spesifiseerbaar en dus moeilik verteenwoordigbaar met 'n IFA-simbool (Abberton, Hazan \& Fourcin, 1990). Dit is dus moontlik dat die dowe reëlmatighede in sy eie spraak gebruik wat nie deur die normaalhorende luisteraar identifiseerbaar is nie.

Die teenwoordigheid en die aard van spraakreëls is egter vir die klinikus van groot belang met die oog op die ontwikkeling van rehabilitasiestrategië. Terapie is tradisioneel nie dieselfde vir 'n persoon met 'n konstant foutiewe reël, die met variasie in produksie van dieselfde klank en die persoon met geen spraakklankreël nie. Die prognose vir terapie sal ook verskillend wees in die geval van'n individu met geen spraakreël nie en vir die persoon waar daar alreeds 'n foutiewe reël vasgelê is (Stoel-Gammon \& Dunn, 1985).

Dit is derhalwe duidelik dat die identifikasie van die dowe se spraakreëls, indien enige, belangrik is. Tot op hierdie stadium is die probleem dat daar nie 'n klinies bruikbare metode is om die spraakreëls te identifiseer nie. Die studies wat die reëlmatighede aangetoon het, het dit slegs vanuit 'n teoretiese oogpunt benader, instrumentele analises gebruik wat nie vir die klinikus beskikbaar is nie, byvoorbeeld elektromiografiese studies en nie gepoog het om die spraakreëls van 'n individu aan te toon nie (byvoorbeeld Monsen, 1976; Huntington; Harris \& Sholes, 1968). Een van die redes is dat slegs enkele klanke ondersoek is en in die meeste gevalle is die studies net op die fonetiese vlak van spraakproduksie, met ander woorde in betekenislose eenhede, uitgevoer (Metz, 1980; Huntington et al., 1968). Die gebruik van die spraakreëls as 'n kommunikasiemedium, waar spraakklanke betekenisonderskeidend aangewend word (op die fonologiese vlak), word nie op die wyse ondersoek nie. 'n Tradisionele fonologiese ontleding (byvoorbeeld Grunwell, 1982) is onbevredigend aangesien die swak spraakverstaanbaarheid van die dowe spreker transkripsie van die spraak feitlik onmoontlik maak. 'n Tradisionele "artikulasietoets" het verskeie probleme (Ling, 1976) waarvan een is dat die onkonstantheid in die dowe se produksie nie in ag geneem word met die enkele ontlokking van 'n foneem in 'n spesifieke konteks nie. Om die spraakreëls dus te kan bepaal, moet die metode vir die spraakopleier uitvoerbaar wees en ook in staat wees om die konstanthede, indien teenwoordig in die spraakproduksie van die dowe, uit te lig.

Die studie het dus ten doel om te bepaal of daar reëlmatighede in geselekteerde uitinge van die Afrikaanssprekende dowe deur luisteraarsbeoordelings geïdenti-

2 Spraakopleier verwys na die persoon wat die spraakopleiding van die dowe doen. Dit kan die oudioloog of die onderwyseres indie skool vir dowes wees. fiseer kan word. Deur spesifieke spraakvoorbeelde van die dowes op 'n herhaalde wyse te ontlok en luisteraars die voorbeelde te laat beoordeel, kan bepaal word of die dowes foneme konstant produseer en of luisteraars ooreenstem ten opsigte van die foneme wat hulle hoor.

\section{METODE}

\section{Proefpersone}

Die twee groepe proefpersone, naamlik dowe sprekers en normaalhorende luisteraars word afsonderlik bespreek.

\section{Dowe sprekers}

Die proefpersone moes verteenwoordigend wees van dowes waar slegs 'n gehoorverlies voorkom het dat die omgewing se spraakreëls spontaan aangeleer kon word. Hulle moet dus geen ander probleme as slegs 'n ernstige (71-91 dB) en uitermatige ( $>91 \mathrm{~dB}$ ) kongenitale sensoriesneurale gehoorverlies openbaar nie en verby die aktiewe periode van spraak- en taalaanleer wees (Bess \& McConnell, 1981). Seuns in standerd agt, nege en tien met ernstige en uitermatige kongenitale sensories-neurale gehoorverliese is in 'n Afrikaanse skool vir dowes geïdentifiseer. Die seuns met 'n normale intellektuele vermoë volgens hul skoolprestasie en vorige IK-toetsing en met horende Afrikaanssprekende ouers wat sedert kleutertyd 'n skool vir dowes bygewoon het, is vervolgens geselekteer. Sewe proefpersone het aan die vereistes voldoen. Hulle het 'n gemiddelde spraakverstaanbaarheidskaaltelling van tussen 1.5 en 3.8 op'n vyf-punt-skaal (Meyer, 1984) behaal met een as onverstaanbaar en vyf as volkome verstaanbaar gestel. Die skaaltelling is bereken deur die gemiddeld van ses beoordelaars.

\section{Normaalhorende luisteraars}

Vrywillige studente in hul derde jaar van die B.Log.graad aan die Universiteit van Pretoria is as beoordelaars van die spraakuitings gebruik. Hulle is reeds opgelei om breë transkripsies van abnormale spraak te doen. Die studente (ouderdom wissel van 20 tot 22 jaar), beskik oor normale gehoor en het slegs beperkte indien enige blootstelling aan die spraak van dowes gehad. Dertien van die studente het Afrikaans as moedertaal, terwyl een haarself as tweetalig beskou.

\section{Apparaat}

'n Sony Stereo Cassette Corder TC-158 SD Bandopnemer met twee Sher-O-Dyne Model 533SA mikrofone is vir die opname van die spraakvoorbeelde in 'n stil vertrek by die skool gebruik. Die perseptuele beoordelings is in die Taallaboratorium van die Universiteit van Pretoria gedoen. Die Taallaboratorium is tóegerus met ' $n$ Tandberg model IS-10 apparaat. Elke luisteraar het vir die ouditief- perseptuele beoordelings ' $n$ TDK $D 60$ band ontvang wat deur middel van' $n$ individuele kopstuk (Tandberg TLH 12) en na gelang van persoonlike luidheidsvoorkeur beoordeel moes word. 'n Enkele luisteraar het 'n Phillips D-6280 bandspeler vir die beoordelings gebruik. 
Tabel 1: Gehoorgestremde sprekers en eienskappe vir seleksie

\begin{tabular}{|l|l|l|l|l|l|l|lc|}
\hline Spreker & $\begin{array}{l}\text { Ouder- } \\
\text { dom }\end{array}$ & $\begin{array}{c}\text { Graad } \\
\text { van verlies }\end{array}$ & $\begin{array}{c}\text { Oorsaak } \\
\text { van verlies }\end{array}$ & Aanvang & $\begin{array}{c}\text { Ouderdom: } \\
\text { diagnose }\end{array}$ & $\begin{array}{c}\text { Ander } \\
\text { probleme }\end{array}$ & $\begin{array}{c}\text { Spraakver- } \\
\text { staanbaarheid }\end{array}$ \\
\hline EEN & $\begin{array}{l}17 \mathrm{jr} \\
6 \mathrm{mnde}\end{array}$ & uitermatig & onbekend & kongenitaal & 11 mnde & geen & 123 & 1.5 \\
\hline TWEE & $\begin{array}{l}17 \mathrm{jr} \\
3 \mathrm{mnde}\end{array}$ & uitermatig & onbekend & kongenitaal & 17 mnde & geen & 105 & 1.8 \\
\hline DRIE & $\begin{array}{l}16 \mathrm{jr} \\
11 \mathrm{mnde}\end{array}$ & ernstig & onbekend & kongenitaal & 30 mnde & geen & 93 & 2.7 \\
\hline VIER & $19 \mathrm{jr}$ & uitermatig & Waardenburg & kongenitaal & 32 mnde & geen & 101 & 2.5 \\
\hline VYF & $\begin{array}{l}19 \mathrm{jr} \\
9 \mathrm{mnde}\end{array}$ & uitermatig & onbekend & kongenitaal & 24 mnde & geen & 122 & 1.8 \\
\hline SES & $\begin{array}{l}18 \mathrm{jr} \\
6 \mathrm{mnde}\end{array}$ & uitermatig & onbekend & kongenitaal & 18 mnde & geen & 100 & 3.8 \\
\hline SEWE & $\begin{array}{l}20 \mathrm{jr} \\
1 \mathrm{mnd}\end{array}$ & uitermatig & onbekend & kongenitaal & 24 mnde & geen & 114 & 1.5 \\
\hline
\end{tabular}

\section{Materiaal vir die ontlokking van die spraskvoorbeelde}

In 'n poging om die spraakreëls van die dowe op 'n klinies toepasbare wyse te bepaal, is daar verskeie vereistes gestel, naamlik:

- Die eksperimentele taak en die materiaal wat gebruik word, moet geskik vir die dowe spreker wees.

- Verskeie herhalings van die spraakvoorbeelde moet versamel word sodat reëlmatighede of produksiestabiliteit, bepaal kan word.

- Die woordstruktuur moes eenvoudig wees sodat dit met gemak deur 'n dowe gelees en uitgespreek kan word. Daar is besluit om KVK-woorde te gebruik. Die KVKwoorde wat geselekteer is, is minimale pare om op 'n gekontroleerde analitiese wyse te bepaal of geselekteerde kontraste inderdaad afwesig of teenwoordig is. Slegs die toetsvokaal is gevarieer en die konsonante is as $/ \mathrm{b}$ - $\mathrm{t} /$ konstant gehou. Die konstante klankomgewing is belangrik in die perseptuele beoordelings sodat die beoordelaars nie enige addisionele inligting kry wat die beoordeling van die toetsklank beïnvloed nie. Elke woord is vyf keer herhaal sodat daar van elke vokaal in 'n spesifieke kontekstuele omgewing vyf produksies is.

- Dit is nie moontlik om alle spraakreëls te bestudeer nie en daarom is slegs vokale geselekteer.

Vokale is geselekteer na aanleiding van die volgende kriteria:

Slegs enkelvokale is oorweeg, aangesien dịe dowe duurverskille in vokaalproduksie, selfs al is die produksie abnormaal, behou en duurverskille in Afrikaans kontrasterend gebruik word, byvoorbeeld man teenoor maan (Meyer, 1984). Die abnormale hoë voorvokaal $[y]$ is ook uitgelaat aangesien die vokaal dikwels as ongerond uitgespreek word en dus as [i] of [ə] realiseer (Meyer, 1984). Slegs vokale wat in die [b-t] klankomgewing voorkom is verder ingesluit en om die rede is [ae] weggelaat. Vokale moes ook verteen- woordigend wees van die Afrikaanse vokale en is dus geselekteer om hoë, neutrale en lae, sowel as voor-, middel-en agter-vokale in te sluit, naamlik /a, i, u, $\varepsilon$, a, d (Wissing, 1982; De Villiers \& Ponelis, 1987). Die woorde vir die vokaalontleding is: boet, bot, bad, bed, bied en bid.

- Aangesien verskeie faktore 'n effek op die duur van klanke het, byvoorbeeld die spraakspoed, die posisie van die woord in 'n sin, die betekenis van die woord, klem van die woord in die sin (Nickerson, Stevens, Boothroyd \& Rollins, 1974, Lehiste, 1970), is alle toetswoorde in dieselfde sin geplaas, naamlik " $\mathrm{Ek}$ het...........gesê".

- Die toetssinne is individueel op wit $10 \times 20 \mathrm{~cm}$ kaarte aangebring waarop die toetswoord in donker en onderstreepte font verskyn. 'n Swart en wit lyntekening wat die woordbetekenis illustreer, is telkens op die kaart aangebring om sodoende die betekenisvolheid van die woord te verseker.

\section{Optekening van data}

Die beoordelaars het 'n geslotekeuseantwoordblad ontvang waarop hul response aangeteken moet word. Die responsmetode is geselekteer aangesien die sprekers as gevolg van hul swak verstaanbaarheid besonder swak sou vaar op'n onbeperkte-keuse-responswyse (Osberger, 1992). Die alternatiewe is geselekteer om die korrektheid van die volgende fonetiese kontraste te evalueer, naamlik vertikale tongposisie of tonghoogte (bied/bad; boet/ bad), horisontale tongposisie (bied/boet; bed/bot), lipvorming (bied/buut; bid/bot; bed/bot) en duur (bat/ baat; bed/beet; bot/boot). Daar was met ander woorde 10 moontlikhede waaruit die luisteraar 'n keuse moes maak sowel as 'n vraagtekenkategorie. Die vraagteken-kategorie is ook ingesluit om inligting te verkry wanneer die spreker se distorsie nie 'n bekende identifiseerbare vorm aanneem nie (Owens, Talbott \& Schubert, 1968). 


\section{Prosedure}

\section{Prosedure vir dataversameling}

1) 'n Stil vertrek is geselekteer sodat die agtergrondgeraas op die opnames so laag moontlik vir die versekering van akkurate analises is.

2) Die doel van die eksperiment is kortliks aan elke proefpersoon verduidelik en die eksperimentele taak is uiteengesit.

3) Die kaarte met toetsstimuli is omgekeerd op die tafel voor die spreker geplaas en die mikrofone is ongeveer 20 sentimeter regs, voor die spreker se mond op 'n tafel geplaas om die effek van die kamerakoestiek sover moontlik te beperk.

4) Daar is dan oorgegaan om die voorbeelde van die toetssinne aan die spreker voor te hou om te verseker dat hy begryp wat van hom verwag word.

5) Die sprekers is daarna gevra om die woorde op die kaarte op 'n natuurlike wyse te lees. Wanneer die ondersoeker seker was dat die spreker weet wat van hom verwag word en dat hy die opdrag kan uitvoer, is tot die oudio-opnames van die eksperimentele sinne oorgegaan.

\section{Prosedure vir die perseptuele ontleding}

6) Al die beoordelaars is opgelei vir die luistertaak deurdat die navorser twee sprekers se spraak saam met die groep beoordeel het.

7) Die beoordelaars het elk hul eie oudioband ontvang waarop die toetssinne van 'n spesifieke spreker gekopieer is met 'n vel papier waarop 'n beperkte keuse van elke toetsitem aangebring is. 'n Voorbeeld van die toetsitems is : "Ek het bad, baat, boet, bot, boot, biet, beet, bid, bed, buut ? ...gesê."

8). Elke spreker se sinne is deur twee luisteraars beoordeel. Elke luisteraar is slegs vir die ontleding van een spreker se uitinge gebruik om te voorkom dat daar ' $n$ orde-effek voorkom deurdat die beoordelaars die daaropvolgende sprekers beter beoordeel as gevolg van hul blootstelling aan die navorsingstaak (McGarr, 1983).

\section{Analise van data}

9) 'n Punt is aan elke korrekte foneembeoordeling toegeken. 'n Vervangingstelling word ook bereken deur die aard van die beoordelaars se "foutiewe" response (die beoordelings wat nie die mik. puntfoneem bevat nie) te ondersoek. Indien dieselfde foneem vir 70 of meer persent waargeneem is, is dit as die vervangingsfoneem beskou.

10) Die beoordelaarsresponse is ook nagegaan om 'n kontrastelling op te teken (Boothroyd, 1985). Die kontraste naamlik tonghoogte of vertikale tongposisie (hoog, middel, laag), horisontale tongposisie (voor, sentraal, agter), duur (kort, lank) en lipstand (de Villiers \& Ponelis, 1987; Wissing, 1982) is ondersoek. Die kontraste lewer 'n totaal van 40 (vier kontraste, vyf herhalings, twee luisteraars) moontlike korrekte response per proefpersoon per foneem.

11) Die response is verder in die vorm van 'n beoordelingsmatriks vir elke spreker opgestel met die doel om patroonmatigheid in die luisteraarsresponse visueel voor te stel.

12) Die interluisteraar-korrelasiekoëffisiënt is .93 wat dui op betroubare luisteraarsbeoordelings (Downie \& Heath, 1971).

\section{RESULTATE}

Resultate van die luisteraarsbeoordelings van die dowes se vokaalproduksie as 'n groep.

In tabel 2 word die vokaal wat deur die luisteraars waargeneem is horisontaal en die teikenvokaal vertikaal in die beoordelingsmatriks se selle ingevul. Die getal in die selle is die frekwensie waarmee elke teikenwaargenome vokaalpaar voorgekom het. Die persentasie korrekte produksie sowel as die persentasie waarmee 'n spesifieke vokaal as vervanger gebruik word, word ook verskaf. Elke vokaal is deur 14 luisteraars beoordeel.

Beskrywing van die resultate van die vokaalbeoordelings van die dowes as 'n groep.

Uit tabel 2 is dit duidelik dat die ses toetsvokale met'n verskeidenheid vokale vervang word. Die sprekers behaal 'n persentasie korrekte produksie van slegs $46.6 \%$. Die

Tabel 2. Beoordelingsmatriks van die gehoorgestremdes se vyf herhalings van die vokale.

\begin{tabular}{|c|c|c|c|c|c|c|c|c|c|c|c|c|}
\hline \multicolumn{13}{|c|}{ Waargenome foneem } \\
\hline & $\mathbf{a}$ & a: & $\mathbf{i}$ & $\mathbf{y}$ & e: & $\varepsilon$ & a & o & o: & $\mathbf{u}$ & Totaal & \% korrek \\
\hline $\mathbf{a}$ & 51 & 2 & 0 & 1 & 0 & 7 & 9 & 0 & 0 & 0 & 70 & $72.9^{\prime}$ \\
\hline i & 14 & 3 & 11 & 1 & 1 & 30 & 9 & 0 & 1 & 0 & 70 & 15.7 \\
\hline$\varepsilon$ & 14 & & 9 & 4 & 2 & 34 & 7 & 0 & 0 & 0 & 70 & 48.6 \\
\hline$a$ & 16 & 1 & 0 & 0 & 0 & 5 & 41 & 0 & 1 & 6 & 70 & 58.5 \\
\hline o & 13 & 6 & 2 & 2 & 0 & 1 & 1 & 19 & 1 & 25 & 70 & 27.1 \\
\hline $\mathbf{u}$ & 8 & 8 & 1 & 4 & 0 & 0 & 2 & 6 & 1 & 40 & 70 & 57.1 \\
\hline Totaal & 116 & 20 & 23 & 12 & 3 & 77 & 69 & 25 & 4 & 71 & 420 & 46.6 \\
\hline$\%$ vervang & 15.5 & 4.8 & 2.9 & 2.9 & .7 & 10.2 & 6.7 & 1.4 & .95 & 7.4 & 53.4 & \\
\hline
\end{tabular}


vokale wat die meeste korrek $^{3}$ geproduseer word is $/ \mathrm{a}$ $(73 \%)$, /a/ (59\%) en $/ \mathbf{u} /(57 \%)$. Hierdie foneme, sowel as die /ə/, word ook algemeen as vervangingsvokale gebruik.

Dit is verder opvallend dat selfs die beste geproduseerde vokale (/a/ teen $73 \%$ ) 'n relatief lae persentasie korrekte produksie behaal het. Die vokaal wat die meeste probleme opgelewer het, is die /i/ waar die sprekers slegs $16 \%$ behaal.

\section{Bespreking van die resultate van die vokaalbeoor-} delings van die dowes as 'n groep.

Die beoordelingsmatriks (kyk tabel 2) illustreer die swak produksie van vokale duidelik. Vokale word deur ten minste drie ander vokale vervang. Die swak vokaalproduksie van die dowe spreker is alreeds deeglik in verskeie tale gedokumenteer (Angelocci, Kopp \& Holbrook, 1964; Meyer, 1984; Odendaal, 1981; Suonpää \& Aaltonen, 1981). Die huidige studie bevestig dan ook die resultate waar 'n maksimun persentasie korrekte vokaalproduksie van slegs $47 \%$ verkry is.

Die prestasie is egter beter as in ander studies wat ook op Afrikaanssprekende proefpersone uitgevoer is. Meyer (1984) verkry byvoorbeeld 33\% en Odendaal (1981) $21 \%$. Die verskil is egter waarskynlik aan die aard van die beoordelingstaak toe te skryf. In hierdie studie is van 'n geslote-keusetaak gebruik gemaak terwyl die ander studies die luisteraars ' $n$ vrye keuse in die beoordelings gegee het. Dit is bekend dat die prestasie in 'n geslote-keusetaak beter as in 'n vrye keuse is (Osberger, 1992).

Oor die algemeen blyk dit dat die lae en die sentrale vokale meer dikwels korrek uitgespreek word en dat die voorvokale meer dikwels probleme oplewer (Gold, 1980) soos ook in die huidige studie die geval is. Die verklaring wat hiervoor voorgehou word, is dat dowes geneig is om hul tonge laag en na agter in die mondholte te hou. Daar word gemeen dat dowes die tongstand verkies omdat dit taktiele leidrade verskaf (Boone, 1966). Die tongplasing het uiteraard 'n negatiewe effek op die voorvokale se resonansiepatrone.

Wanneer die hoorbaarheid van die vokaalformantfrekwensies in gedagte gehou word, kan die beter produksie van /a/ en / $/$ / verklaar word. Beide die vokale se eerste en tweede formante is in 'n relatief lae frekwensiegebied geleë (Meyer, 1984).

Die sentrale /a/ vokaal se relatief geslaagde produksie is ook in ooreenstemming met vorige studies. Daar word algemeen gemeen dat die ontspanne natuurlike tongposisie /a/'n maklik produseerbare vokaal maak.

Die relatief ongeslaagde produksie van $/ \mathrm{a} /$ (slegs $27 \%$ korrekte produksie is behaal) is nie duidelik nie. Dit is 'n vokaal waar beide die eerste en die tweede formante in die frekwensiegebied onder $1000 \mathrm{~Hz}$ geleë is (Peterson \& Barney, 1952) en dus hoorbare leidrade vir die produksie behoort te bied. Nogtans berig Owens et al. (1968) dat dowes die vokaal dikwels foutief waarneem. Daarbenewens is dit ook 'n vokaal wat sigbare leidrade in die vorm van lipronding bied, wat ook korrekte produksie kan bevorder. Daar is egter verskeie ander studies wat die dowes se probleme met die vokaal aantoon (Meyer, 1984; Odendaal, 1981).

Die swak produksie van $/ \mathrm{j}$ is egter nie onverwags nie,

3 Korrek moet gelees word as "korrek identifiseerbaar" aangesien die spraak van al die sprekers die kenmerkende afwykings van die dowe vertoon. en is ook al in vorige studies en in ander tale bevind (Geffner, 1980; Meyer, 1984; Odendaal, 1981). Die hoë voortongposisie verskaf min taktiele leidrade (Boone, 1966) en die hoë tweede formantfrekwensie maak die vokaal moeilik hoorbaar (Meyer, 1984; Peterson \& Barney, 1952). Die spreker het met ander woorde min inligting tot sy beskikking om sy produksie van die vokaal te rig, wat tot die swak produksie aanleiding gee.

Alhoewel duurversteurings dikwels in die vokaalproduksie van die dowe se spraak voorkom (Parkhurst \& Levitt, 1978), was dit nie 'n opvallende kenmerk van die huidige studie nie. Daar is spesifiek net kort vokale vir die navorsingstaak geselekteer, en die luisteraars het slegs met uitsondering'n lang /a:/ $(4.7 \%)$, /e:/ $.7 \%)$, en $/ 0: /(.95 \%)$ in plaas van kort vokale gehoor. Dit is steeds moontlik dat die sprekers hul toetsvokale verleng, maar dat dit nie as lang vokaal relatief tot die res van die sin gehoor word nie, aangesien die totale uiting se duur verleng is. Dit is dan ook reeds opgeteken dat die dowe spreker, ten spyte van algemene verlenging van vokale, die relatiewe duur van sy vokale behou (Meyer, 1984).

Die laaste opvallende bevinding is dat alle vokale nie ewe veel as vervangingsvokale gebruik word nie. Die $/ \varepsilon /$ en die / $/$ / word algemeen as vervangingsvokale gebruik. $\mathrm{Die} / \varepsilon /$ word hoofsaaklik as die vervangingsvokaal van die /i/ gebruik. Beide vokale is voorvokale en het 'n relatief lae eerste formant. Die tweede formant van die / $\varepsilon$ / is egter laer as die van die /i/ (Meyer, 1984) wat dit waarskynlik makliker hoorbaar maak. Die /a/ daarenteen, word vir'n wye verskeidenheid vokale as vervanging gebruik sodat daar nie so 'n duidelike patroon voorgekom het nie. Wat egter opvallend is, is dat/a/ eerder as die neutrale vokaal lo/ as "algemene" vervangingsvokaal gebruik word. Afgesien van die /a/ se hoorbaarheid soos reeds genoem, bied die middellae tongposisie moontlik taktiele terugvoeringsleidrade wat produksie vergemaklik. Die vervangingspatroon het veroorsaak dat die tradisionele vokaalneutraliserings (Levitt, Stromberg, Smith, \& Gold, 1980) nie in die groep sprekers se spraak opgeval het nie.

Die bestudering van die data van die groep as geheel, het interessante patrone na vore gebring met die uitstaande indruk dat die dowe spreker oor swak vokaalproduksie beskik. Die samevoeging van die groepsdata verskuil egter die moontlikheid van enige hoorbare patroonmatigheid in die vokaalproduksie van die individuele dowe spreker. In 'n poging om die individuele patroonmatigheid na te gaan, sal die beoordelingsmatrikse van die sprekers afsonderlik bestudeer word.

\section{Resultate van die luisteraarsbeoordelings van individuele dowe sprekers}

In tabel 3 word die vokaalbeoordelingsmatriks vir Spreker Een aangetoon. Die vokaal wat deur die luisteraars waargeneem is, is horisontaal en die vokaal wat die spreker geproduseer het of die teikenvokaal, vertikaal in die beoordelingsmatriksselle ingevul. Die getal in die selle is die frekwensie waarmee elke teiken-/ waargenome vokaalpaar voorgekom het. Elke vokaal is deur twee luisteraars beoordeel en die persentasie korrekte beoordeling vir elke vokaal asook die persentasie korrekte beoordeling vir al die vokale gesamentlik word aangetoon. Die asterisk by 'n selinskrywing toon aan dat 'n luisteraar in al vyf beoordelings dieselfde vokaal gehoor het. Die persentasie waarmee 'n spesifieke vokaal as vervangingsvokaal gebruik is, word ook aangegee. 
Tabel 3. Vokaalbeoordeling van Spreker Een Waargenome foneem

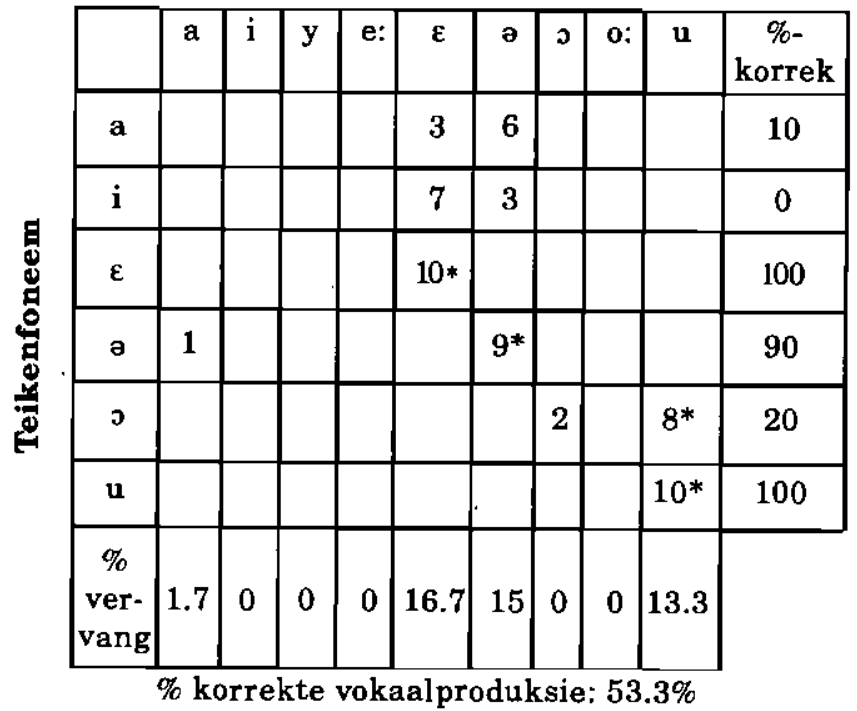

Beskrywing van die resultate van die vokaalbeoordelings van Spreker Een

Uit tabel 3 blyk dit dat die die spreker 'n persentasie korrekte vokaalproduksie van $53 \%$ behaal het en dat die luisteraars / $/$ /, /a/ en / $\mathrm{u} /$ korrek kon hoor. Hulle het egter met goeie eenstemmigheid 'n foutiewe maar reëlmatige produksie van $/ \mathrm{i} /$ as $/ \varepsilon / \mathrm{en} / \mathrm{s} /$ as $/ \mathrm{u} /$ gehoor. Die spreker het met ander woorde slegs drie in plaas van die ses vokale in sy foneemskat. Die vokale wat hy korrek produseer, word ook as vervangingsvokale vir die ander gebruik.

In tabel 4 word die vokaalbeoordelingsmatriks vir Spreker Twee afsonderlik aangetoon. Die uiteensetting is soos in tabel 3.

\section{Beskrywing van die resultate van die} vokaalbeoordelings van Spreker Twee.

Uit tabel 4 blyk dit duidelik dat die luisteraars nie enige ander vokaal as /a/ konstant kon hoor nie. Die spreker maak met ander woorde nie enige verskil in die produksies van $/ \mathrm{a} / \mathrm{i} / \mathrm{i} / \mathrm{/a} / \mathrm{en} / \mathrm{s} / \mathrm{soos}$ deur die luisteraars waargeneem nie. Dit is ook interessant dat $/ \varepsilon / \mathrm{en} / \mathrm{u} / \mathrm{vir}$ 'n geringe aantal herhalings as korrek waargeneem is maar dat 'n groot

Tabel 4. Vokaalbeoordelings van Spreker Twee Waargenome foneem

\begin{tabular}{|c|c|c|c|c|c|c|c|c|c|c|}
\hline & $\mathbf{a}$ & i & $\mathrm{y}$ & e: & $\varepsilon$ & a & o & $0:$ & $\mathbf{u}$ & $\begin{array}{c}\%- \\
\text { korrek }\end{array}$ \\
\hline a & $10^{*}$ & & & & & & & & & 100 \\
\hline $\mathbf{i}$ & $9 *$ & & & & & & & 1 & & 0 \\
\hline$\varepsilon$ & 6 & & & & 3 & 1 & & & & 30 \\
\hline a & $8^{*}$ & & & & & & & 1 & 1 & 0 \\
\hline J & $9 *$ & & & & & & & 1 & & 0 \\
\hline $\mathbf{u}$ & 6 & & & & & & & 1 & 3 & 30 \\
\hline $\begin{array}{c}\% \\
\text { ver- } \\
\text { vang }\end{array}$ & 63.3 & 0 & 0 & 0 & 0 & 1.6 & 0 & 6.6 & 1.6 & \\
\hline
\end{tabular}

Tabel 5. Vokaalbeoordeling van Spreker Drie Waargenome foneem

\begin{tabular}{|c|c|c|c|c|c|c|c|c|c|c|}
\hline & $\mathbf{a}$ & $i$ & $y$ & e: & $\varepsilon$ & $a$ & כ & o: & $\mathbf{u}$ & $\begin{array}{c}\%- \\
\text { korrek }\end{array}$ \\
\hline a & $10^{*}$ & & & & & & & & & 100 \\
\hline i & & 1 & 1 & & $5^{*}$ & 3 & & & & 10 \\
\hline$\varepsilon$ & & & 3 & & $5^{*}$ & 2 & & & & 50 \\
\hline a & & & & & & $10 *$ & & & & 100 \\
\hline ग & & & & & & & 2 & & $8^{*}$ & 20 \\
\hline $\mathbf{u}$ & & & & & & & & & $10^{*}$ & 100 \\
\hline $\begin{array}{c}\% \\
\text { ver- } \\
\text { vang }\end{array}$ & 0 & 0 & 6.6 & 0 & 8.3 & 8.3 & 0 & 0 & 13.3 & \\
\hline
\end{tabular}

aantal van die produksies ook as /a/ gehoor is. In plaas van ses foneme gebruik die spreker slegs een foneem. Dit is dus nie onverwags dat hy slegs $23 \%$ korrekte vokaalproduksie behaal nie.

In tabel 5 word die vokaalbeoordelingsmatriks vir Spreker Twee afsonderlik aangetoon. Die uiteensetting is soos in tabel 3.

\section{Beskrywing van die resultate van die vokaalbeoordelings van Spreker Drie.}

Uit tabel 5 blyk dit die luisteraars $/ a /, / u /$ en $/ /$ konstant korrek kon hoor. Die enigste ander vokaal wat'n konstant hoorbare patroon gegee het, is $/ 2 /$ wat as $/ \mathrm{u} /$ gehoor is. Die ander vokale is as verskillend gehoor, en die spreker behaal 'n relatief hoë persentasie korrekte produksie, naamlik $62 \%$.

Dit was egter interessant dat die luisteraars nie dieselfde inligting uit die uitings verkry het nie. Die vokaal $/ \mathcal{E}$ is konstant korrek gehoor deur die een luisteraar en ook as die konstante vervangingsklank vir die /i/gehoor (aangedui met *). Die ander luisteraar het egter nie

Tabel 6. Vokaalbeoordelings van Spreker Vier Waargenome foneem

\begin{tabular}{|c|c|c|c|c|c|c|c|c|c|c|}
\hline & $\mathbf{a}$ & $\mathbf{i}$ & $y$ & e: & $\varepsilon$ & $\partial$ & ग & o: & $\mathbf{u}$ & $\begin{array}{c}\%- \\
\text { korrek }\end{array}$ \\
\hline a & $7^{*}$ & & & & & 3 & & & & 70 \\
\hline i & & 1 & 1 & & 5 & 3 & & & & 10 \\
\hline$\varepsilon$ & & & 1 & & $5 *$ & 4 & & & & 50 \\
\hline a & & & & & & $10 *$ & & & & 100 \\
\hline $\boldsymbol{\jmath}$ & & & 2 & & 1 & & $5 *$ & & ' & 50 \\
\hline $\mathbf{u}$ & & & 2 & & & 2 & $5^{*}$ & & 1 & 10 \\
\hline $\begin{array}{c}\% \\
\text { ver- } \\
\text { vang }\end{array}$ & 0 & 0 & 10 & 0 & 10 & 15 & 8.3 & 0 & 3.3 & \\
\hline
\end{tabular}


dieselfde konstante inligting uit die/i/en/\&/uitings verkry nie, want sy het die vokale, hoofsaaklik $/ y /$ of $/ a /$ gehoor.

In tabel 6 word die vokaalbeoordelingsmatriks vir Spreker Twee afsonderlik aangetoon. Die uiteensetting is soos in tabel 3.

Beskrywing van die resultate van die vokaalbeoordelings van Spreker Vier.

Uit tabel 6 blyk dit duidelik dat die luisteraars slegs in die geval van /a/ en /a/die vokale as korrek kon hoor. Die ander vokale is egter nie as patroonmatig waargeneem nie. Verskeie vokale is met /a/ vervang, terwyl / $/$ / en $/ \jmath /$ ook dikwels in plaas van ander foneme gehoor is. Van die ses toetsvokale wil dit voorkom asof die spreker /a/

Tabel 7. Vokaalbeoordelings van Spreker Vyf Waargenome foneem

\begin{tabular}{|c|c|c|c|c|c|c|c|c|c|c|}
\hline & $\mathrm{a}$ & $\mathrm{i}$ & $\mathrm{y}$ & $\mathrm{e}:$ & $\varepsilon$ & $\mathrm{a}$ & $\mathrm{J}$ & $\mathrm{o}:$ & $\mathrm{u}$ & $\begin{array}{c}\%- \\
\text { korrek }\end{array}$ \\
\hline $\mathrm{a}$ & $8^{*}$ & 2 & & & & & & & & 80 \\
\hline $\mathrm{i}$ & 5 & 3 & & & 2 & & & & & 0 \\
\hline $\mathrm{E}$ & 8 & & & & 2 & & & & & 20 \\
\hline $\mathrm{o}$ & $7^{*}$ & 1 & & & & 2 & & & & 20 \\
\hline $\mathrm{o}$ & 4 & 6 & & & & & & & & 0 \\
\hline $\mathrm{u}$ & 2 & 8 & & & & & & & & 0 \\
\hline $\begin{array}{c}\% \\
\mathrm{ver}- \\
\text { vang }\end{array}$ & 43.3 & 33.3 & 0 & 0 & 3.3 & 0 & 0 & 0 & 0 & \\
\hline
\end{tabular}

$\%$ korrekte vokaalproduksie: $20 \%$

kontrasteer met voorvokale wat deur $/ \varepsilon /$ verteenwoordig word en agtervokale wat deur $/ \mathrm{s} /$ verteenwoordig word. $\mathrm{Die} / \mathrm{a} /$ word as algemene vervangingsfoneem aangewend. Ten spyte van die beperkte foneemskat behaal die spreker $47 \%$ korrekte produksie.

In tabel 7 word die vokaalbeoordelingsmatriks vir Spreker Twee afsonderlik aangetoon. Die uiteensetting is soos in tabel 3.

\section{Beskrywing van die resultate van die vokaalbeoordelings van Spreker Vyf.}

Uit tabel 7 blyk dit dat die luisteraars net een vokaal, naamlik die /a/, korrek kan identifiseer. Die /a/ word dan ook as algemene vervangingsfoneem gehoor. Die spreker kontrasteer /a/ en /u/ skynbaar deur middel van 'n duurverskil, waar die / $\mathrm{w} /$ met 'n langer duur uitgespreek word. Daar is egter geen ander duidelike patroon wat uit die data na vore kom nie en hy behaal slegs $20 \%$ korrekte produksie.

In tabel 8 word die vokaalbeoordelingsmatriks vir Spreker Twee afsonderlik aangetoon. Die uiteensetting is soos in tabel 3.

\section{Beskrywing van die resultate van die} vokaalbeoordelings van Spreker Ses.

Uit tabel 8 blyk dit dat die luisteraars eenstemmig was ten opsigte van die korrektheid van die produksies van vier van die vokale. Daar is ook nie onduidelikheid ten
Tabel 8. Vokaalbeoordelings van Spreker Ses Waargenome foneem

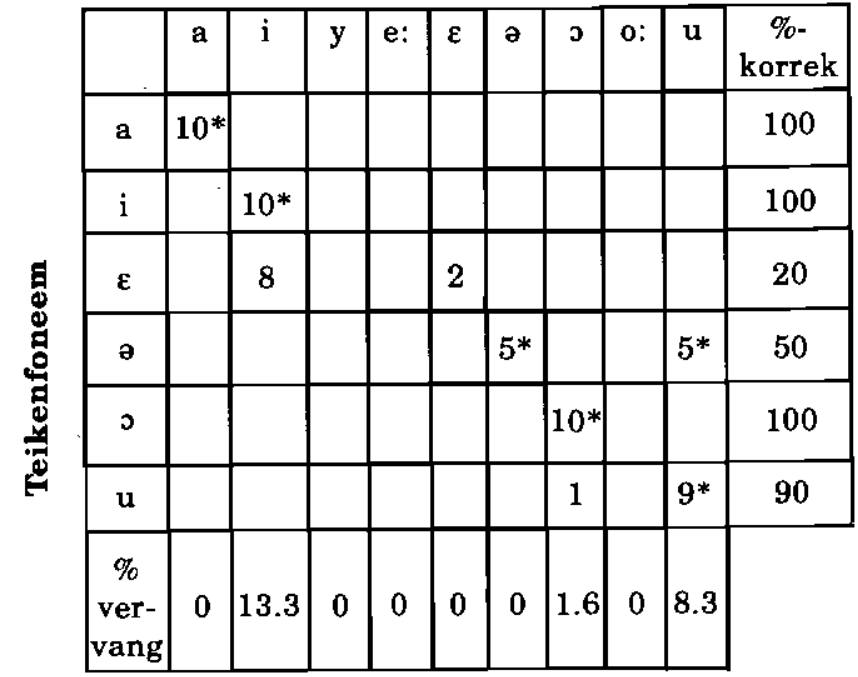

\% korrekte vokaalproduksie: $76.6 \%$

opsigte van die / $/$ wat met redelike goeie konstantheid met die $/ \mathrm{i} /$ vervang is nie.

Daar was egter' $n$ verskil in opinie tussen die luisteraars oor die korrektheid van die /o/. Die een het gemeen dat die vokaal korrek uitgespreek is terwyl die ander dit as 'n konstante vervanging met $/ \mathrm{w}$ gehoor het.

Die spreker gebruik vier in plaas van die ses toetsvokale. Hy tref geen onderskeiding tussen $/ \mathrm{i} /$ en $/ \varepsilon /$ nie en sy produksie van /ə/ is nie duidelik nie. Hy behaal $62 \%$ korrekte vokaalproduksie.

In tabel 9 word die vokaalbeoordelingsmatriks vir Spreker Twee afsonderlik aangetoon. Die uiteensetting is soos in tabel 3.

\section{Beskrywing van die resultate van die} vokaalbeoordelings van Spreker Sewe.

Uit tabel 9 blyk dit dat die luisteraars slegs die / $/$ en $\mathrm{die} / \mathrm{u} /$ as korrek beoordeel het. Hulle was ook eenstemmig dat die spreker nie enige onderskeid tref tussen $/ \mathrm{i} /$ en $/ \varepsilon /$ nie en ook nie tussen $/ \mathrm{J} / \mathrm{en} / \mathbf{w} /$ nie. Die ander beoordelings vertoon nie 'n duidelike patroon nie. Hy behaal dan ook slegs $40 \%$ korrekte produksie.

Tabel 9. Vokaalbeoordelings van Spreker Sewe Waargenome foneem

\begin{tabular}{|c|c|c|c|c|c|c|c|c|c|c|}
\hline & a & i & $\mathrm{y}$ & e: & $\varepsilon$ & $\partial$ & 0 & o: & $\mathbf{u}$ & $\begin{array}{c}\%- \\
\text { korrek }\end{array}$ \\
\hline a & 5 & & 1 & & 4 & & & & & 50 \\
\hline $\mathbf{i}$ & & & & 1 & $8^{*}$ & 1 & & & & 0 \\
\hline$\varepsilon$ & & 1 & & 2 & $7^{*}$ & & & & & 70 \\
\hline ə & & & & & 5 & 5 & & & & 50 \\
\hline o & & 2 & & & & 1 & & & 7 & 0 \\
\hline $\mathbf{u}$ & & 1 & 2 & & & & & & $7^{*}$ & 70 \\
\hline $\begin{array}{c}\% \\
\text { ver- } \\
\text { vang }\end{array}$ & 0 & 6.7 & 5 & 5 & 28.3 & 3.3 & 0 & 0 & 11.7 & \\
\hline
\end{tabular}

$\%$ korrekte vokaalproduksie: $40 \%$ 
Bespreking van die resultate van die vokaalbeoordelings van individuele dowe sprekers.

Die individuele beoordelingsmatrikse van die sprekers toon dat daar groot individuele verskille ten opsigte van die persentasie korrekte vokaalproduksie, wat wissel van 20 tot 62 persent, bestaan. Alhoewel die luisteraars nie in staat was om al ses vokale in enige van die sprekers se spraakmonsters te identifiseer nie, kon hulle vier by Spreker Ses teenoor slegs een by Spreker Twee hoor.

Nog 'n interessante verskil tussen die verskillende sprekers was die vokale wat die luisteraars as korrek kon identifiseer. Die /a:/ is deur 5 sprekers (Sprekers Twee, Drie, Vier, Vyf en Ses) die / $\mathrm{u}$ / deur vier (Sprekers Twee, Drie, Vier en Ses) en /a/deur drie (Sprekers Een, Drie, en Vier) korrek gebruik. Die ander vokale was korrek deur een $(/ \mathrm{i} /, / \mathrm{s} /)$ of twee $(/ \ell /)$ sprekers (Sprekers Een en Sewe) gebruik. Dit dui ook net weer op die individuele patrone in die vokaalproduksie by die sprekers.

Die verskil in die vervangingsvokale wat die luisteraars kon hoor, was ook opvallend tussen die sprekers. Die vokale wat as vervangingsvokale gebruik is, was in die meeste gevalle die vokale wat die spesifieke spreker ook korrek kan produseer. Dit gee dan outomaties aanleiding tot individuele verskille soos in die vorige paragraaf verduidelik is.

Alhoewel daar aanvaar word dat dowes nie dieselfde foute vertoon nie, lewer die studie 'n bydrae ten opsigte van die klem wat op individuele foutpatrone geplaas word. Groepsdata soos in verskeie studies (Gold, 1980; Odendaal, 1981) en soos in tabel 2 verskaf, verbloem die individuele foutpatrone wat in die dowes se spraak na vore kom wanneer die individuele data bestudeer word. Dit lei tot die foutiewe aannames dat "dowe spraak" nie ook individuele patrone vertoon nie.

Die individualiteit van 'n spreker se fonologiese stelsel is van groot belang in terapie. Öster (1991) noem dat 'n afwykende produksie sistematies en stabiel oor tyd kan wees en dat dit die realisering van 'n afwykende reël kan wees. Indien terapie gegee word sonder bewustheid van bestaande kontraste in die kind se spraak en dus bestaande verbindings tussen die fonetiese realisering en die abstrakte linguistiese vlak, kan dit tot die verval van die kind se sisteem en tot ' $n$ afname in verstaanbaarheid lei.

Dit is verder belangrik om daarvan bewus te wees dat dit nie raadsaam is om op slegs 'n enkele uiting staat te mak om die dowe se produksiekennis te evalueer nie. Die variasie in die beoordelings van die sprekers het duidelik uit die beoordelingsmatrikse geblyk. Dit is duidelik dat sommige vokale op 'n lukraak wyse geproduseer word, soos blyk uit die/a/van Spreker Sewe. Die variasie in produksie sou nie uit 'n enkele spraakvoorbeeld duidelik geword het nie.

'n Laaste opmerking ten opsigte van die luisteraarsbeoordelings is dat dit wil voorkom asof luisteraars - nie dieselfde "perseptuele strategieë" gebruik in die beoordeling van die spraak van die sprekers nie. (Wanneer 'n luisteraar telkens in elk van die lyste dieselfde vokaal gehoor het wanneer die spreker 'n spesifieke toetswoord geproduseer het, is dit met 'n asterisk in die matrikse aangetoon.) Daar is uiteraard niks vreemd omtrent die beoordelings waar 'n spreker 10 in die selinskrywing ontvang het nie. Dit impliseer slegs dat beide luisteraars die geproduseerde vokale as korrek beoordeel het.
Wanneer een luisteraar egter konstant'n spesifieke vokaal hoor, terwyl die ander luisteraar konstant'n ander vokaal hoor (kyk Spreker 6, vokaal /a/) of verskeie ander vokale hoor (kyk byvoorbeeld Spreker 4, vokaal / $/$ /) kan daar moontlik van verskillende luisterstrategieë gepraat word. Om die aspek verder te ondersoek is die interluisteraarsbetroubaarheidskoëffisiënt van die kontrastellings van die twee luisteraars wat elke spreker beoordeel het, ondersoek.

\section{Resultate van die interluisteraarsbetroubaar- heidskoëffisiënt van die kontrastellings van die luisteraars}

In tabel $\mathbf{1 0}$ is die interluisteraarsbetroubaarheidskorrelasiekoëffisiënt vir die twee luisteraars bereken deur die kontrastellings vir die vyf herhalings van elke van die ses toetsvokale teenoor mekaar te stel.

Beskrywing van die interluisteraarsbetroubaarheidskoëffisiënt van die kontrastellings van die luisteraars

Uit tabel 10 blyk dit dat die korrelasiekoëffisiënte wissel vanaf 0.49 tot 0.98 . Die rede waarom daar so 'n goeie korrelasie in sommige en so 'n swak korrelasie in ander gevalle bestaan, kan net oor gespekuleer word, veral gesien in die lig van die interluisteraarkorrelasie van 0.93 .

Luisteraarsbeoordelings is tradisioneel die metode van keuse vir die evaluasie van afwykende spraak (Kearns \& Simmons, 1988). Dat dit moeilik vir selfs 'n hoogs opgeleide luisteraar is om die spraak van die dowe te beoordeel, is algemeen bekend (Monsen, 1978). Dit is problematies om die oorsaak van die fout te onttrek omdat spraak nie 'n eenvoudige liniêre string simbole is nie, maar 'n ingewikkelde gekoartikuleerde kode. Die feit dat die twee luisteraars egter nie dieselfde kontrastellings behaal nie, dui op verskillende luisterstrategieë. Dit is moontlik dat sekere luisteraars van die kontraste wat in die spreker se spraak voorkom, suksesvol kan benut, terwyl dit nie vir 'n ander luisteraar duidelik genoeg is om te benut nie. Die abnormaliteit in die spraak van die spreker verbloem moontlik die kontras vir so 'n luisteraar.

Dit is immers bekend dat die luisteraar, selfs 'n opgeleide fonetikus, nie'n spraakanalise kan doen sonder om deur konvensionele terminologie en linguistiese ondervinding beïnvloed te word nie (Clark \& Yallop,|1990). In die geval van hierdie luisteraars, slegs opgelei om breë fonetiese transkripsies te doen, sou bogenoemde invloed

Tabel 10. Korrelasie-koëffisiënt vir vokaalbeoordelings van elke spreker se twee luisteraars

\begin{tabular}{|c|c|}
\hline Luisteraars van & Korrelasie-koëffisiënt \\
\hline Spreker 1 & .93 \\
\hline Spreker 2 & .74 \\
\hline Spreker 3 & .49 \\
\hline Spreker 4 & .56 \\
\hline Spreker 5 & .98 \\
\hline Spreker 6 & .76 \\
\hline Spreker 7 & .71 \\
\hline
\end{tabular}


moontlik nog sterker kon wees. Die luisteraars wat vir die studie geselekteer is, is waarskynlik tiperend van die persone wat vir die dowe se spraakopleiding verantwoordelik sal wees en die bevindings is dus van belang vir die spraakopleier.

In teenstelling met die hipotese van individuele luisterstrategieë, is Harris et al. (1985) van mening dat luisteraars, hetsy gesofistikeerd of ongesofistikeerd, nie oor 'n spesiale strategie beskik om dowes se vokale te dekodeer nie. Die studie spreek egter nie spesifiek die resultate van individuele luisteraars aan soos die huidige navorsing nie. Die feit dat luisteraars in hierdie studie in die beoordeling van dieselfde spreker se uitings verskil, bevestig die hipotese dat daar moontlik van verskillende luisterstrategieë sprake is. Wanneer die uitings waaroor hulle saamstem bestudeer word, kom interessante inligting na vore en dit word vervolgens verskaf.

Resultate van die ooreenstemming in die luisteraarsbeoordelings van die dowe sprekers se segmentele produksie

In tabel 11 word die resultate van die twee luisteraars se beoordelings van elke spreker weergegee. Wanneer sewe van die tien beoordelings ooreengestem het, word die resultaat as 'n duidelike patroon in die produksie van die uiting beskou. Wanneer al die beoordelings egter tussen slegs twee segmente gewissel het met ongeveer ewe veel beoordelings in elk is dit ook aangetoon soos byvoorbeeld in die geval van die a/u-inskrywings. Indien die luisteraars se beoordelings oor ' $n$ aantal selle verspreid was, is daar nie 'n hoorbare konstantheid in die produksie van die spesifieke foneem nie.

Beskrywing en verklaring van die ooreen-stemming in die luisteraarsbeoordelings van die dowe sprekers se segmentele produksie

Uit'tabel 11 blyk dit duidelik dat daar sekere foneme is wat meer dikwels deur die luisteraars korrek waargeneem kon word as ander. Die /a/ is 'n mikpuntfoneem wat deur vyf of ses van die sewe sprekers gebruik is. Die vokale /i/en / / lewer opvallend dikwels probleme. Die luisteraars kon selde hoor dat'n spreker die mikpuntfoneme konstant korrek gebruik.

Dit val verder op dat die sprekers nie een dieselfde vervangingspatroon vertoon nie. Alhoewel daar ooreenkomste tussen die sprekers is, is daar nie by enige twee sprekers presies dieselfde mikpuntfoneme wat korrek gebruik word of wat met dieselfde foneem vervang word nie.

Dit is ook duidelik uit tabel 11 dat die sprekers sommige van die kontraste van die korrekte mikpuntfoneem behou het, byvoorbeeld in die geval van / $\mathrm{i} /$ is die vervangingsfoneem $/ \varepsilon$. Beide die teiken- en die vervangingsvokaal is voorvokale alhoewel die plek van vorming nie korrek is nie.

Die individualiteit van die sprekers se segmentproduksie blyk duidelik uit die bespreking. Die sprekers het patroonmatigheid getoon en mikpuntfoneme op 'n konstante wyse gerealiseer sodat beide beoordelaars oor ten minste $70 \%$ van dieselfde foneem se realiserings saamgestem het. Dit dui op die gebruik van kontraste op 'n sistematiese wyse. Die individualiteit van die sprekers se foutpatrone is waarskynlik te wyte aan hul individuele sensoriese en omgewingsomstandighede.

\section{GEVOLGTREKKING}

Die resultate van die studie toon aan dat dit wel moontlik is om spraakreëls in geselekteerde uitinge van die Afrikaanssprekende dowe deur middel van luisteraarsbeoordelings te bepaal.

Uit hierdie studie het daar belangrike feite na vore gekom. Eerstens het dit geblyk dat die luisteraars se segmentbeoordelings aangetoon het dat die groep dowe sprekers se produksie in 'n groot mate ooreenstem met wat reeds in die literatuur berig is. Die lae voorkoms van korrek geïdentifiseerde foneme is reeds in verskeie studies aangetoon en is weer in die studie bevestig.

Tweedens was dit duidelik dat sekere mikpuntfoneme met konstantheid gerealiseer word terwyl dit nie by ander die geval is nie. Dit was ook opvallend dat die dowes individuele verskille getoon het ten opsigte van die vokale wat hulle korrek kon produseer en die vokale wat hulle as vervangingsvokale gebruik.

Derdens is daar bevind dat daar verskille tussen luisteraars na vore getree het. Die verskille toon aan dat die luisteraars, indien hulle dieselfde produksie moet beoordeel, nie noodwendig dieselfde foneem identifiseer nie.

Die metode wat hier gebruik is, het beperkinge aangesien die monsters nie spontane spraak is nie en die linguistiese vaardigheid van die spreker nie bepaal word nie. Die verstaanbaarheid van die uitings sal beïnvloed word deur die sintaktiese en leksikale probleme wat nie op die wyse geïdentifiseer word nie (Boothroyd, 1985). Deur egter die uitings te beperk, te laat herhaal en op 'n

Tabel 11. Konstanthede identifiseerbaar in elke gehoorgestremde spreker se vokaalproduksie deur twee luisteraars.

\begin{tabular}{|c|c|c|c|c|c|c|c|c|}
\hline $\begin{array}{l}\text { Toets- } \\
\text { foneem }\end{array}$ & $\begin{array}{c}\text { Spreker } \\
1\end{array}$ & $\begin{array}{c}\text { Spreker } \\
2\end{array}$ & $\begin{array}{c}\text { Spreker } \\
\mathbf{3}\end{array}$ & $\begin{array}{c}\text { Spreker } \\
4\end{array}$ & $\begin{array}{c}\text { Spreker } \\
5\end{array}$ & $\begin{array}{c}\text { Spreker } \\
6\end{array}$ & $\begin{array}{c}\text { Spreker } \\
7\end{array}$ & $\begin{array}{l}\text { Aantal } \\
\text { korrek }\end{array}$ \\
\hline a & geen & $\mathbf{a}$ & $\mathbf{a}$ & a & $\mathbf{a}$ & a & geen & 5 \\
\hline i & $\varepsilon$ & $\mathbf{a}$ & geen & geen & $\mathrm{a} / \mathrm{a}:$ & $\mathrm{i}$ & $\varepsilon$ & 1 \\
\hline$\varepsilon$ & $\varepsilon$ & geen & geen & $\varepsilon$ & $\mathbf{a}$ & i & $\varepsilon$ & 3 \\
\hline$a$ & a & $\mathbf{a}$ & $\theta$ & ə & $\mathbf{a}$ & a/u & ${ }^{\circ} / \varepsilon$ & 3 \\
\hline 0 & $\mathbf{u} \quad$ । & a & $\mathbf{u}$ & geen & a/a: & o & $\mathbf{u}$ & 1 \\
\hline $\mathbf{u}$ & $\mathbf{u}$ & geen & $\mathbf{u}$ & geen & a: & $\mathbf{u}$ & $\mathbf{u}$ & 4 \\
\hline
\end{tabular}


geslotekeusebasis te beoordeel, kan die spraakopleier 'n idee vorm of 'n segment op 'n konstante wyse uitgespreek word en die spreker dus oor 'n reël vir die produksie beskik. Die kennis kan tot meer effektiewe terapiebeplanning bydra.

\section{ERKENNINGS}

Die personeel en die skoliere van die Transoranje-skool vir Dowes word vir hul vriendelike samewerking bedank.

Erkenning word gegee aan die finansiële bystand van die Raad van Geesteswetenskaplike Navorsing. Opvattings en gevolgtrekkings wat gemaak word, is dié van die skrywer en word nie noodwendig deur die Raad onderskryf nie.

\section{VERWYSINGS}

Abberton, E. Hazan, V. \& Fourcin, A. (1990). The development of contrastiveness in profoundly deaf children's speech. Clinical Linguistics and Phonetics, 4, 209-220.

Angelocci, A., Kopp, G. \& Holbrook, A. (1964). The vowel formants of deaf and normal hearing eleven to fourteen year old boys. Journal of Speech and Hearing Disorders, $29,156-170$

Bess, F.H. \& McConnell, F.E. (1981). Audiology Education, and the Hearing Impaired child. St. Louis: The C.V. Mosby Company.

Boone, D.R. (1966). Modification of the voices of deaf children. The Volta Review, 68, 686-692.

Boothroyd, A. (1978). Speech perception and sensori neural hearing loss. In Ross, M. \& Giolas, T.G. (Eds). Auditory Management of Hearing Impaired Children. Principles and Prerequisites for Intervention. Baltimore: University Park Press.

Boothroyd, A. (1985). Evaluation of speech production of the hearing impaired: Some benefits of forced-choice testing. Journal of Speech and Hearing Research, 28, 185-196.

Clark, J. \& Yallop, C. (1990). An Introduction to Phonetics and Phonology. Oxford: Basil Blackwell.

De Villiers, M. \& Ponelis, F.A. (1987). Afrikaanse Klankleer. Kaapstad: Tafelberg-Uitgewers.

Downie, N.M.\& Heath, R.W. (1970). Basic Statistical Methods (3rd ed.) New York: Harper \& Row Publishers.

Fry, B.D. (1978). The role and primacy of the auditory channel in speech and language development. In: Ross, M. and Giolas, T.G. (Eds). Auditory Management of Hearing Impaired Children. Principles and Prerequisites for Intervention. Baltimore: University Park Press.

Geffner, D. (1980). Feature characteristics of spontaneous speech production in young deaf children. Journal of Communication Disorders, 13, 443-454.

Gold, T. (1980). Speech production in hearing-impaired children. Journal of Communication Disorders, 13, 397-418.

Grunwell, P. (1982). Clinical Phonology. London: Croom Helm.

Harris, K.S., Rubin-Spitz, J. \& McGarr, N.S. (1985). The role of production variability in normal and deviant developing speech. Proceedings of the Conference on the Planning and Production of Speech in Normal and Hearing Impaired Individuals. ASHA Reports, 15, 50-57.

Huntington, D.A., Harris, K.S. \& Sholes, G.N. (1968). An electromyographic study of consonant articulation in hearing impaired and normal speakers. Journal of Speech and Hearing Research, 11, 147-158.

Kearns, K.P. \& Simmons, N.N. (1988). Interobserver reliability and perceptual ratings: More than meets the ear. Journal of Speech and Hearing Research, 31, 131-136.

Lehiste, I. (1970). Suprasegmentals. Cambridge: The MIT Press.
Levitt, H., Stromberg, H., Smith, C. \& Gold, T. (1980). The structure of segmental errors in the speech of deaf children. Journal of Communication Disorders, 13, 419-441.

Ling, D. (1976). Speech and the Hearing Impaired Child: Theory and Practice. Washington, D.C.: Alexander Graham Bell Association for the Deaf.

Manilal, S. (1992). Attitudes of deaf adolescents towards speech language hearing therapy. Unpublished BA (Sp \& Th) research report, Department of Speech Pathology and Audiology University of the Witwatersrand, Johannesburg.

McGarr, N. (1983). The intelligibility of deaf speech to experienced and inexperienced listeners. Journal of Speech and Hearing Research, 26, 451-458.

Metz, D.E. (1980). Morphological boundaries and the timing of stressed vowels produced by profoundly hearing impaired adults. Journal of Phonetics, 8, 63-68.

Metz, D.E., Schiavetti, N., Sitler, R.W. \& Samar, V.J. (1990) Speech production stability characteristics of hearing impaired speakers. The Volta Review, 92, 223-235.

Meyer, S.E. (1984). Die vokaalproduksie van die Afrikaanssprekende gehoorgestremde. Ongepubliseerde M.Log Verhandeling, Universiteit van Pretoria.

Monsen, R.B. (1974). Durational aspects of vowel production in the speech of deaf children. Journal of Speech and Hearing Research, 11, 386-398.

Monsen, R.B. (1976). The production of English stop consonants in the speech of deaf children. Journal of Phonetics, 4, 29-41.

Monsen, R.B. (1978). Toward measuring how well hearing impaired children speak. Journal of Speech and Hearing Research, 21, 197-219.

Nickerson, R., Stevens, K., Boothroyd, A. \& Rollins, A. (1974), Some observations on timing in the speech of deaf and hearing speakers. Report No 2905. Cambridge, MA:Bolt Beranek and Newman, Inc.

Odendaal, J.E. (1981). 'n Ondersoek na luisteraars se beoordeling van die artikulasie van vokale deur dowe en normaalhorende sprekers. Ongepubliseerde BA (log) verhandeling. Universiteit van Pretoria.

Osberger, M.J. (1987). Training effects on vowel production by two profoundly hearing impaired speakers. Journal of Speech and Hearing Research, 30, 24-251.

Osberger, M.J. (1992). Speech intelligibility in the hearing impaired: Research and clinical applications. In: Kent, R.D. (Ed). Intelligibility in Speech disorders. Theory, Measure. ment and Management. Amsterdam: John Benjamins Publishing Co.

Öster, A-M. (1991). Phonological assessment of eleven prelingually deaf children's consonant production. Speech Transmission Laboratory-Quarterly Progress and Status Report, 2-3, 11-18.

Owens, E., Talbott, C.B. \& Schubert, E.D. (1968). Vowel discrimination of hearing-impaired listeners. Journal of Speech and Hearing Research, 11, 648-655.

Parker, A. \& Rose, H. (1990). Deaf children's phonological development. In: Grunwell, P. (Ed). Develópmental Speech Disorders. Edinburgh: Churchill Livingstone.

Parkhurst, B. \& Levitt, H. (1978). The effect of selected prosodic errors on the intelligibility of deaf speech. Journal of Communication Disorders, 11, 249-256.

Peterson, G. \& Barney, H. (1952). Control methods used in a study of the vowels. Journal of the Acoustical Society of America, 24, 175-184.

Stoel-Gammon, C. \& Dunn, C. (1985). Normal and Disordered Phonology in Children. Baltimore; MD: University Park Press.

Suonpää, J. \& Aaltonen, O. (1981). Intelligibility of vowels in words uttered by profoundly hearing-impaired children. Journal of Phonetics, 9, 445-450.

Wissing, D.P. (1982). Algemene en Afrikananse Generatiewe Fonologie. Johannesburg: Macmillan. 